\title{
The missing gonadotropin-releasing hormone agonist trigger leading to missing oocytes
}

\author{
Rama S. Kadam, Navroze M. Jassawalla, Priyanka H. Vora*, Mehernosh J. Jassawalla
}

Department of Reproductive Medicine, Nowrosjee Wadia Maternity Hospital, Parel, Mumbai, Maharashtra, India

Received: 27 April 2020

Accepted: 30 May 2020

\section{*Correspondence:}

Dr. Priyanka H. Vora,

E-mail: priyav865@gmail.com

Copyright: (c) the author(s), publisher and licensee Medip Academy. This is an open-access article distributed under the terms of the Creative Commons Attribution Non-Commercial License, which permits unrestricted non-commercial use, distribution, and reproduction in any medium, provided the original work is properly cited.

\begin{abstract}
Authors present a case of Genuine EFS in a young woman where no oocytes were retrieved in the first stimulation cycle after single ovulation trigger. However, a repeat stimulation performed with double ovulation trigger yielded enough oocytes.
\end{abstract}

Keywords: Empty follicle syndrome, hCG injection, GnRH analogue trigger, Oocyte retrieval

\section{INTRODUCTION}

Empty follicle syndrome (EFS) was first described by Coulam et al. ${ }^{1}$ It is a condition in which no oocytes are retrieved from the mature follicle after ovulation induction in in vitro fertilization (IVF) cycles with apparently normal growing follicles with normal steroidogenesis after meticulous follicular aspiration. The incidence of this syndrome has been estimated at 0.2 $7.0 \% .^{2,3}$

\section{CASE REPORT}

25-year-old lady, 3 years into her active married life with BMI of 17.24 was diagnosed with primary infertility. Her $\mathrm{AMH}$ was $4.83 \mathrm{ng} / \mathrm{ml}$ with antral follicle count of 10 in each ovary. Her hormonal profile was normal. Hysterosalpingography was suggestive of bilateral blocked tubes at the level of the isthmus with a normal uterine cavity. Husband's semen parameters demonstrated severe oligo-asthenozoospermia (count - 2 million/ml with forward progressive motility - 1\%) and serum FSH of 2.3. IU/ml. The couple was counselled for oocyte retrieval followed by intracytoplasmic sperm injection (ICSI) and the same was consented upon. Ovulation induction was done with Antagonist protocol using injectable gonadotropins (10 doses) $300 \mathrm{mg}$ I.M. (Menotas HP; Intas) and GnRH antagonist (6 doses) 0.25 Ug S.C. (Cetrolix; Intas). Ovarian response was adequate, with serum estradiol (E2) levels of $2846 \mathrm{pg} / \mathrm{ml}$ and serum progesterone (P4) levels of $1.04 \mathrm{ng} / \mathrm{ml}$. This was followed by a single ovulation trigger of injection human chorionic gonadotropin (hCG) 10,000 IU I.M. (Coriosurge XP; Intas).

Serum B-hCG levels, done 12 hours post-trigger was found to be $87.9 \mathrm{IU} / 1$. Oocyte retrieval was done 35 hours post-trigger. However, there was a total lack of oocytes obtained on retrieval in the stimulation cycle. Subsequently, the patient was willing to undergo a repeat stimulation cycle. In this cycle, authors used the same protocol for an equal duration which resulted in an adequate ovarian response on ultrasound with E2 levels of $4782 \mathrm{pg} / \mathrm{ml}$ and P4 levels of $0.532 \mathrm{ng} / \mathrm{ml}$.

However, authors triggered the patient with dual ovulation trigger of injection hCG 10,000 IU I.M. (Coriosurge XP; Intas) plus GnRH agonist injection Leuprolide acetate $2 \mathrm{mg}$ S.C. (Luprorin-4; Intas). Serum B-hCG and LH levels were $118.4 \mathrm{IU} / 1$ and $>100 \mathrm{IU} / \mathrm{ml}$ respectively, 12 hours post-trigger. This oocyte retrieval yielded 19 oocytes, 14 of which were in metaphase 2 on 
which ICSI was performed. A total of 9 day 3 embryos were formed all of which were cryopreserved.

\section{DISCUSSION}

\section{Empty follicle syndrome is of two types}

- Genuine EFS - where there is failure to retrieve oocytes with mature ovarian follicles after controlled ovarian hyperstimulation in an assisted reproductive technology cycle despite adequate hCG/LH levels on day of oocyte retrieval and

- False EFS - failure to retrieve oocytes due to low hCG levels ( $<40 \mathrm{IU} / \mathrm{L})$ due to error in administration /low hCG bioavailability. $33 \%$ of EFS are genuine and $67 \%$ are false. ${ }^{4}$

The risk factors for genuine EFS include advanced maternal age, ovarian aging, prolonged infertility, higher base line FSH and lower E2 level before hCG injection. ${ }^{5}$ Risk factors for false EFS include the "pharmaceuticals industry syndrome" (a defect arising at any level from production, packaging up to storage of the drug) leading to abnormality in the in-vivo biological activity of hCG/ $\mathrm{GnRH}$ agonist, inappropriate hCG timing (trigger taken late/another day by mistake), subcutaneous hCG administration in extremely obese (may not act adequately in which case intramuscular route is the safest) and rapid hCG elimination by the liver. Post trigger, it is the hCG that leads to softening of connective tissue which subsequently leads to detachment of oocyte cumulus complex (occ) from the wall causing drop of occ mass into the follicular fluid which is then aspirated during retrieval. However, failure of hCG to do the above or prolongation of the above after hCG is the main pathophysiology behind EFS. It can also occur due to altered folliculogenesis or dysfunctional folliculogenesis (follicles may go into atresia despite apparently normal hormonal response) or could be genetic in some cases. Risk of recurrence of EFS is $20 \%$ and increases with advanced maternal age viz $24 \%$ at 35 years and $57 \%$ at $>40$ years. ${ }^{6,7}$ Post GnRH agonist trigger, LH surge after 18 hours leads to Meiosis 1 and the whole conversion to metaphase 2 (stage 2 of meiosis 1) is complete in 36 hours. EFS is the result of either an inadequate LH surge or derangement in occ complex or an intrinsic oocyte factor or the aspirated oocytes not reaching M2 phase (not maturing due to absent meiotic recombination in pachytene stage/ inability to produce key cell regulating factors). Probably, this was the missing link to the lack of oocytes in this case first retrieval cycle. Also, GnRH agonist trigger causes FSH surge, which leads to LH receptor formation in the luteinizing granulosa cells. Strickland and Beers in 1976 stated that FSH is a plasminogen activator which increases the plasmin content in the follicular fluid which in turn produces "collagenase" disrupting the follicular wall and detaching the occ from it. ${ }^{8}$ Onalan et al reported EFS as an inherited genetic disorder found in two sisters affected with moderate sensorineural deafness. Jisic $\mathrm{V}$ et al showed
EFS may occur either due to presence of pericentric inversion of chromosome 2:46XX, inv (2) (p11q21) or inherited mutation of $\mathrm{LH} / \mathrm{hCG}$ receptor identified in two sisters with EFS.9-11 Hence, the diagnosis of EFS is mostly retrospective. Treatment for genuine EFS is either repeat cycle with same/ different protocol or use double trigger/recombinant hCG to trigger the $\mathrm{LH}$ surge/recombinant LH. In False EFS, re-administer hCG (recombinant/urinary), assess hCG/LH adequacy, maintain cold chain, always confirm trigger with patient prior to oocyte retrieval in order to help rescheduling of the same. Avoid triggering of hypogonadotrophic hypogonadal and long protocol patients with $\mathrm{GnRH}$ agonist trigger. Also curette the follicles post aspiration as they may be stuck to the follicular wall. ${ }^{8,12}$

\section{CONCLUSION}

Dominant follicles in patients undergoing retrieval may not always be empty and if dealt with correctly do contain oocytes. The role of GnRH agonist trigger although known is not always used as a standard. As an IVF specialist a shift can be made to using the double trigger in almost all feasible cases to avoid such mishaps of repeat oocyte retrievals

Funding: No funding sources

Conflict of interest: None declared

Ethical approval: Not required

\section{REFERENCES}

1. Coulam CB, Bustillo M, Schulman JD. Empty follicle syndrome. J Fertil Steril. 1986;46:1153-5.

2. Aktas M, Beckers NG, Van Inzen WG. Oocytes in the empty follicles: a controversial syndrome. J Fertil Steril. 2005;84(6):1643-8.

3. Awonuga A, Govindbhai J, Zierke S. Continuing the debate on empty follicle syndrome: can it be associated with normal bioavailability of $\beta$-HCG on the day of oocyte recovery? J Hum Reprod. 1998;13(5):1281-4.

4. Stevenson TL, Lashen H. Empty follicle syndrome: the reality of a controversial syndrome, a systemic review. J Fertil Steril. 2008;90(3):691-8.

5. Baum M, Machtinger R, Yerushalmi GM. Recurrence of empty follicle syndrome with stimulated IVF cycles. J Gynecol Endocrinol. 2012;28(4):239-5.

6. Zegers-Hochschild F, Fernandez E, Machenna A, Faberes C. The EFS: a pharmaceutical industry syndrome. J Hum Reprod. 1995;10:2262-5.

7. Zreik TG, Gracia-Velasco JA, Vergara TM. EFS: evidence for recurrence. J Hum Repro. 2000;15(5):999-1002.

8. Beck-Fruchter R, Weiss A, Lavee M, Geslevich Y, Shalev E. Empty follicle syndrome: successful treatment in a recurrent case and review of the literature. J Hum Reprod. 2012;27(5):1357-67. 
9. Onalan G, Pabuccu R, Onalan R. EFS in two sisters with three cycles: case report. J Hum Repro. 2003;18(9):1864-7.

10. Vujisic S, Stipoljev F, Bauman R. Pericentric inversion of chromosome 2 in a patient with the EFS: case report. J human Reprod. 2005;20(9):2552-5.

11. Yariz KO, Walsh T, Uzak A, Spiliopoulos $M$, Duman D, Onalan G, et al. Inherited mutation of the luteinizing hormone/choriogonadotropin receptor (LHCGR) in empty follicle syndrome. Fertil Steril. 2011;96(2):e125-30.
12. Pennarrubia J, Balasch J, Fabregues F, Creus M, Civico S, Vanrell J. Recurrent EFS successfully treated with recombinant HCG: case report. J Hum Reprod. 1999;14:1703-6.

Cite this article as: Kadam RS, Jassawalla NM, Vora PH, Jassawalla MJ. The missing gonadotropinreleasing hormone agonist trigger leading to missing oocytes. Int J Reprod Contracept Obstet Gynecol 2020;9:3066-8. 